\title{
Countering Abuse in EU Environmental Markets: The Case for Integrated Operational Safeguards
}

\author{
Thoko Kaime*
}

Various European Union (EU) regulatory bodies have championed the use of environmental markets as a key policy tool to achieve environmental protection either in lieu of, or in addition to, more traditional regulatory programmes. When these markets work properly, they have the capacity to provide enhanced levels of environmental quality and can operate as more efficient mechanisms for protecting natural resources that provide vital services to people. However, if regulatory safeguards are absent from the legal frameworks creating such markets, it is unlikely that the theoretical benefits of these arrangements will be realized. This article assesses whether a number of EU environmental markets meet design standards that guard against these risks. It concludes that despite recognition of the danger of market manipulation and outright fraud, to date regulators in the EU have largely responded to these risks largely in an ad hoc and incomplete fashion, rather than embedding the mechanisms for operational accountability into the regulatory frameworks that govern green trading arrangements. Finally, this article identifies and prescribes five essential pillars for market-based programmes for the environment that are necessary to provide operational safeguards. These include informational safeguards, transparency standards, rule of law safeguards, verifiable performance standards and financial fidelity rules.

\section{BACKGROUND}

On 3 March 2016, the European Biodiesel Board (EBB) alerted European Union (EU) regulators about possible trade distortions and fraud in the biodiesel market perpetrated by Polish diesel traders ${ }^{1}$ in contravention of the Renewable Energy Directive (RED) ${ }^{2}$ and the Fuel Quality Directive (FQD). ${ }^{3}$ Key to the EU's climate change and energy strategy, the RED and FQD put in place regulations that mandate an increasing amount of fuel from renewable sources, such as rapeseed, cooking oil and other waste products. In order to reduce carbon emissions from cars and lorries, one element of the RED requires that domestic traders blend diesel fuel with biofuel sourced from local renewable sources. ${ }^{4}$ Instead of blending rapeseed oil or other renewable sources with regular diesel to produce a biofuel, the EBB found that some Polish suppliers were attempting to meet the obligation to provide green fuel at home by simply adding extra diesel to the mix and reserving the fuel made from crops. It is believed that they then passed off regular diesel as the blended variety in the domestic market

\footnotetext{
${ }^{*}$ Corresponding author.

Email: tkaime@essex.ac.uk

${ }^{1}$ European Biodiesel Board (EBB), 'Polish Low-priced Biodiesel Exports Threaten the Level Playing Field in the EU Market' (3 March 2016), found at: <http://www.ebbeu.org/EBBpressreleases/EBB_PR_Polish_low_priced_exports_3March2016_Final.pdf>.

${ }^{2}$ Directive 2009/28/EC of 23 April 2009 on the Promotion of the Use of Energy from Renewable Sources, [2009] OJ L140/16 ('RED').

${ }_{3}^{3}$ Directive 2009/30/EC of 23 April 2009 Amending Directive 98/70/EC as Regards the Specification of Petrol, Diesel and Gas-oil and Introducing a Mechanism to Monitor and Reduce Greenhouse Gas Emissions and Amending Council Directive 1999/32/EC as Regards the Specification of Fuel Used by Inland Waterway Vessels and Repealing Directive 93/12/EEC, [2009] OJ L140/88.

${ }^{4}$ RED, n. 2 above, Annex II.
} 
as well as for export, thereby gaining payments for blended diesel where none had taken place. $^{5}$

The regulatory failure of the Polish biodiesel market is yet another example of systematic manipulation and fraud in a line of cases in the EU involving schemes designed to utilize markets for the provision of environmental services. More importantly, the case demonstrates the pressing need for comprehensive regulatory safeguards and accountability mechanisms in environmental markets because without these, it is likely that strategies for market-based interventions in favour of environmental protection will fall prey to fraud and manipulation. This is particularly important because since the 1970s, market-based interventions have formed a key part of EU regulatory programmes for the protection of the environment and natural resources. ${ }^{6}$ Whilst many of these programmes have produced successful initiatives, their achievements have to be appreciated in the context of widespread fraud that has hampered the operation of some key schemes such as the Polish case described above.

This article is an analytical examination of instances of fraud and manipulation in EU environmental markets. It scrutinizes the problems using recent case studies and seeks to fashion regulatory solutions emerging from the complex nature of the trading regimes themselves as well as the sophisticated nature of the fraud and manipulation.

Consequently, this article focuses on the role of markets in protecting ecosystem services an area in which there is an urgent need for a clear and effective regulatory framework, because momentum for increased reliance on market-based interventions has grown. Drawing on experiences with environmental markets in the EU, the article analyses examples of past abuses to underscore the urgent need for the careful design of these market-based environmental regulatory programmes. More importantly, it uses the failures identified in these case studies to make the case for five operational safeguards that need to be incorporated into such market-based interventions if they are to offer protection against fraud and abuse whilst preserving the potential for cost effective environmental protection. These operational standards include informational safeguards, transparency standards, rule of law safeguards, verifiable performance standards and financial fidelity rules. To date, no EU market for ecosystem services systematically relies on each of these standards to protect the integrity of trading programmes. Used in combination, the operational safeguards advanced here could significantly increase the chances of realising the efficiency benefits of the operation of environmental markets whilst preventing behaviour that relegates environmental public policy goals to manipulative private gain.

\section{ENVIRONMENTAL MARKETS IN THE EU AND EXAMPLES OF PAST ABUSES}

\section{EXAMPLES OF ENVIRONMENTAL MARKETS}

The EU has taken a leading role in the development of environmental markets. Perhaps the best known example is the EU emissions trading system (ETS), ${ }^{7}$ which has been in operation

\footnotetext{
${ }^{5}$ Polish Low-priced Biodiesel Exports, above n1. See also Biofuels International, 'Industry Group Calls for EU Scrutiny on Polish Diesel Exports' (4 March 2016), found at: <http://biofuelsnews.com/display_news/10258/industry_group_calls_for_eu_scrutiny_on_polish_biodiesel_exports/ $>$.

${ }^{6}$ T. Kaime and R. Glicksman, 'A Comparative Analysis of Accountability Mechanisms for Ecosystem Services Markets in the United States and the European Union', 2:2 Transnational Environmental Law (2013), 259.

${ }^{7}$ Directive 2003/87/EC of 13 October 2003 Establishing a Scheme for Greenhouse Gas Emission Allowance Trading Within the Community and Amending Directive 96/61/EC, [2003] OJ L275/32.
} 
since 2005. It is regarded as the first international trading system for carbon dioxide $\left(\mathrm{CO}_{2}\right)$ emissions in the world. ${ }^{8}$ Since 1 January 2008, it has applied to the 27 EU Member States and to 3 members of the European Economic Area (EEA): Norway, Iceland and Liechtenstein. ${ }^{9}$ The EU ETS covers over 11,000 installations in the energy and industrial sectors, which are responsible for almost half of the EU's $\mathrm{CO}_{2}$ emissions, and $40 \%$ of its total greenhouse gas emissions. An amendment to the EU ETS Directive, adopted in July 2008, ${ }^{10}$ agreed to bring the aviation sector into the system beginning in $2012 .^{11}$ The ETS is a cap-and-trade system, which caps the overall level of emissions allowed. Within that limit, participants in the system are allowed to buy and sell permits, as they require. These permits are the trading 'currency' at the heart of the system. A permit gives the holder the right to emit one tonne of $\mathrm{CO}_{2}$ or the equivalent amount of another greenhouse gas, and the cap on the total number of permits creates scarcity in the market and opportunities for trading.

In addition to the ETS, the EU's Common Agricultural Policy (CAP) ${ }^{12}$ and its related agrienvironmental measures (AEMs) provide mechanisms through which to regulate ecosystem service markets. ${ }^{13}$ Although the CAP is principally an agricultural framework, its AEMs provide incentives to encourage farmers to protect and enhance the environmental attributes of their farmland. ${ }^{14}$ Under these measures, farmers are paid in return for providing an environmental service. Service contracts are signed with a domestic public regulator and farmers are paid for the additional cost of implementing such commitments and for loss of income. The two main objectives are to reduce environmental risks and to preserve nature and cultivated landscapes. AEMs go beyond usual good farming practice ${ }^{15}$ - the standard legal obligations and levels of environmental care that each farmer routinely has to comply with, are compiled in 'regional' codes submitted by Member States to the European

\footnotetext{
${ }^{8}$ See, e.g., A. Papageorgiou et al., 'Emissions Trading Scheme: Evidence from the European Union Countries' in: Creativity in Intelligent, Technologies and Data Science (Springer, 2015), 204; A.D. Ellerman and B.K. Buchner, 'The European Union Emissions Trading Scheme: Origins, Allocation, and Early Results', 1:1 Review of Environmental Economics and Policy (2007), 66; J. Kruger, W.E. Oates and W.A. Pizer, 'Decentralization in the EU Emissions Trading Scheme and Lessons for Global Policy', 1:1 Review of Environmental Economics and Policy (2007), 112.

${ }^{9}$ S. Kallbekken, 'The Cost of Sectoral Differentiation: The Case of the EU Emissions Trading Scheme' (CICERO, 2004).

${ }^{10}$ Directive 2008/101/EC Amending Directive 2003/87/EC so as to Include Aviation Activities in the Scheme for Greenhouse Gas Emission Allowance Trading within the Community, [2009] OJ L8/3.

${ }^{11}$ See A. Anger 'Including Aviation in the European Emissions Trading Scheme: Impacts on the Industry, $\mathrm{CO}_{2}$ Emissions and Macroeconomic Activity in the EU', 16:2 Journal of Air Transport Management (2010), 100; P.M. de Forster, K.P. Shine and N. Stuber, 'It is Premature to Include Non- $\mathrm{CO}_{2}$ Effects of Aviation in Emission Trading Schemes', 40:6 Atmospheric Environment (2010), 1117; J. Scheelhaase, W. Grimme and M. Schaefer, 'The Inclusion of Aviation into the EU Emission Trading Scheme: Impacts on Competition between European and Non-European Network Airlines', 15:1 Transport and Environment (2010), 14.

${ }_{12}$ A. Oskam. 'Understanding the Common Agricultural Policy', 39:4 European Review of Agricultural Economics (2012), 735; W. Grant, 'Policy Instruments in the Common Agricultural Policy', 33:1 West European Politics (2010), 22.

${ }^{13}$ See V. Beckmann, J. Eggers and E. Mettepenningen, 'Deciding How to Decide on Agri-Environmental Schemes: The Political Economy of Subsidiarity, Decentralisation and Participation in the European Union', 52:5 Journal of Environmental Planning and Management (2009), 689; T.L. Dobbs and J. Pretty, 'Case Study of Agri-Environmental Payments: The United Kingdom’, 65:4 Ecological Economics (2008), 765; J. Poláková et al., 'Addressing Biodiversity and Habitat Preservation through Measures Applied under the Common Agricultural Policy' (Institute for European Environmental Policy, 2011), found at: <http://ec.europa.eu/agriculture/analysis/external/biodiversity-protection/full_text_en.pdf>.

${ }^{14}$ Communication from the European Commission, Our Life Insurance, Our Natural Capital: An EU Biodiversity Strategy to 2020, COM(2011) 244, Annex (outlining proposals by the European Commission in which CAP direct payments will lead to the delivery of environmental public goods).

${ }^{15}$ See T.L. Dobbs et al., n. 13 above, at 766.
} 
Commission for approval. Some AEMs concern productive land management, such as input reduction, which includes reduction of fertilizers and plant protection products, crop rotation measures, organic farming, extensification of livestock, conversion of arable land to grassland, under-sowing, cover crops, farmed buffer strips, prevention of erosion and fire and rotation measures, and actions such as late mowing in areas of special biodiversity/natural interest. ${ }^{16}$ Also considered are measures that enhance genetic diversity, maintenance of existing sustainable and extensive systems, farmed landscapes, and water use reduction measures. Other AEMs concern non-productive land management, such as setting aside land, upkeep of abandoned farmland and woodland, and upkeep and maintenance of the countryside and landscape features.

Environmental markets have also emerged in connection with the implementation of international environmental agreements to which the EU is a party. An excellent example of this type of market is the Clean Development Mechanism (CDM) developed as part of the Kyoto Protocol. ${ }^{17}$ Article 12 of the Protocol allows parties to receive credits for participation in projects certified on the basis of their capacity to produce 'real, measurable, and long-term benefits to the mitigation of climate change'. ${ }^{18}$ Among the projects capable of meeting these requirements are renewable energy initiatives and carbon sequestration efforts. For example, developing countries could expand forests that sequester carbon as a means of generating credits. These credits could then be sold to developed countries to help the latter meet their greenhouse gas emission reduction obligations more efficiently than they could have done by pursuing emissions control or other technological solutions. ${ }^{19}$ In 2010 , one observer described the market for greenhouse gas offsets as 'large and rapidly growing,' although forest carbon offsets accounted for a relatively small percentage of the value of all trades. ${ }^{20}$

\section{FRAUDULENT MANIPULATION OF ENVIRONMENTAL MARKETS}

As experience with the CAP AEMs demonstrates, the operation of environmental markets has the potential to achieve ecosystem protection goals at a lower cost than more traditional regulatory techniques. However, these opportunities for efficient environmental protection and improvement are accompanied by risks. One such pitfall is that those who generate and are paid for credits will not follow through with their commitments. Another risk is that such persons would merely implement environment risk reduction measures that do not provide the same levels of environmental service as those that are developed through transactions in the appropriate market. ${ }^{21}$ Additionally, participants in environmental markets may engage in market manipulation or outright fraud. Such illegal conduct thwarts the goals of the particular regulatory programmes to which ecosystem markets are attached, and undercuts the legitimacy of markets in ecosystem services. For example, market participants who claim to

\footnotetext{
${ }^{16}$ See A. Oskam, n. 12 above, at 736-8; T.L. Dobbs et al., n. 13 above, at 766.

${ }^{17}$ Kyoto Protocol to the United Nations Framework Convention on Climate Change (Kyoto, 10 December 1997; in force 16 February 2005) ('Kyoto Protocol'), Article 12. See generally M. Wara, 'Measuring the Clean Development Mechanism's Performance and Potential', 55:6 UCLA Law Review(2008), 1759.

${ }^{18}$ Kyoto Protocol, n. 17 above, Article 12.5(b).

19 D. Hirsch, 'Trading in Ecosystem Services: Carbon Sinks and the Clean Development Mechanism', 22:2 Journal of Land Use and Environmental Law (2007), 623, at 625-626.

${ }^{20}$ A. Davis, 'Ecosystem Services and the Value of Land', 20:2 Duke Environmental Law and Policy Forum (2010), 339, at 353-354.

${ }^{21}$ Kathleen McAfee, 'The contradictory logic of global ecosystem services markets' 43 Development and Change 2012, 105, at 113 ('[ecosystems services] markets are ideal arenas for high-risk investments, fraud and outright thefts, as when computer hackers robbed $€ 30$ million in ETS allowances, and for double-dipping, when credits for the same claimed emissions-avoidance actions are sold to more than one buyer.').
} 
have generated tradable credits may seek to be paid for environmental protections and improvements that would have occurred even without the sale of credits if, for example, these results are required independently by other regulatory programmes (creating an 'additionality' problem). ${ }^{22}$ Participants may seek payment for improvements for which they have already been compensated ('double-dipping'). Participants may even attempt to claim credit for improvements or protections that never occurred ('paper' or 'phantom' trade transactions). ${ }^{23}$ Trading programmes are problematic because they 'create strong incentives to manipulate the numbers and cheat, because credits that are fraudulently created are still worth money'. ${ }^{24}$ Described below are three examples of environmental markets gone bad, each of which involved egregious manipulation of the currencies and systems created by the trading programmes.

The first example relates to the EU's flagship environmental permit trading programme, the EU ETS, which, despite relative success, has faced serious questions relating to fraud, such as the introduction into the market of recycled trading permits and tax fraud. In an attempt to raise revenue, early in 2010 the Hungarian government sold permits known as Certified Emission Reductions (CERs), which had been issued under the Kyoto Protocol's CDM and had already been surrendered by companies to meet their ETS compliance requirements. The government claimed that it sold the credits on the condition that they must not be resold in the EU ETS. However, ten trading houses found they had some of them in their accounts after they bought CERs on the Paris-based trading exchange BlueNext. The news disrupted the carbon market, as ETS exchanges ascertained if their own inventories contained the offending instruments. At least three exchanges reacted by temporarily ceasing all trade in CERs. The European Commission moved to safeguard the ETS by subsequently banning such reuse, but how the credits came to be sold on BlueNext remains unclear. ${ }^{25}$

Tax fraud is another challenge that the ETS has faced. Despite receiving widespread attention recently, fraudulent activity has been a problem for the ETS since $2008 .{ }^{26}$ Of initial concern was value-added tax (VAT) fraud. In some European countries governments treat carbon permits as a taxable consumptive good, with those governments placing a VAT on the transfer of carbon credits. Criminals exploited the tax-code variation among countries by opening trading accounts, buying permits in countries without a tax, and then selling them in countries with a tax. The repeated buying and selling of the permits generated large amounts of money from the VAT that disappeared before the VAT was collected. It has been

\footnotetext{
${ }^{22}$ See D. Cooley and L. Olander, 'Stacking Ecosystem Services Payments: Risks and Solutions' (2012), 42:2 Environmental Law Reporter, 10150, at 10157; G. Achterman and R. Mauger, 'The State and Regional Role in Developing Ecosystem Service Market', 20:2 Duke Environmental Law and Policy Journal (2010), 291, at 325 ('[a]dditionality is the concept that credited ecosystem improvements must "represent an overall increase in, or a [measurable] avoided reduction of, ecosystem services, relative to those services that would have existed without creating the credits"').

${ }^{23}$ D. Driesen and S. Ghosh, 'The Functions of Transaction Costs: Rethinking Transaction Cost Minimalization in a World of Friction', 47:1 Arizona Law Review (2005), 61, at 94 ('[p]aper trades allow operators to escape an applicable emission control requirement in exchange for a claimed reduction that reflects no extra actual emission reduction').

${ }^{24}$ R. Drury et al., 'Pollution Trading and Environmental Injustice: Los Angeles' Failed Experiment in Air Quality Policy', 9:2 Duke Environmental Law and Policy Forum (1999), 231, at 259.

25 Point Carbon - 14 May 2010 quoting Hungarian Government Report, available at: http://www.kvvm.hu/index.php?pid=1\&sid=1\&hid=2640.

${ }^{26}$ K. Nield and R. Pereira. 'Fraud on the European Union Emissions Trading Scheme: Effects, Vulnerabilities and Regulatory Reform', 20:6 European Energy and Environmental Law Review (2011), 255; McKenzie Funk, 'Cap and Fraud'32 Foreign Policy 210 (2015): 32.
} 
estimated that in 2009, EU Member States lost a combined total in excess of $€ 5$ billion (Germany is reported to have lost $€ 850$ million; the Netherlands $€ 300$ million). ${ }^{27}$

The problem of recycled trading permits and tax fraud has emerged in the EU ETS principally because there were no systems designed into the operations of the trading regime for prompt EU-wide exchange of information, performance and transparency standards coupled with stringent financial fidelity rules. Participants in the Hungarian CER scheme were therefore able to shift and dump their holdings into BlueNext without alarm being raised promptly. Similarly, the lack of information sharing allowed the variations in tax-code frameworks that ultimately allowed VAT-based fraud to thrive. The fact that it took several years before this situation was arrested attests to the lack of robust operational standards designed to tackle fraud and manipulation in the ETS.

The perverse operation of environmental markets is also exhibited by the Kyoto Protocol's CDM. The carbon credits available under the CDM are valued according to the impact on global warming and the staying power in the atmosphere of particular greenhouse gases once they are emitted into the environment. Methane $\left(\mathrm{CH}_{4}\right)$, for example, is 21 times more powerful an agent of atmospheric warming than $\mathrm{CO}_{2}{ }^{28}$ The warming potential of nitrous oxide $\left(\mathrm{N}_{2} \mathrm{O}\right)$ is 298 times greater than that for $\mathrm{CO}_{2} \cdot{ }^{29}$ The chemical HFC-23, a byproduct of manufacturing of HCFC-22 (a refrigerant and feedstock for certain plastic products), is 11,700 times more potent as a greenhouse gas than $\mathrm{CO}_{2}{ }^{30}$ Between the initiation of the trading programme and mid-2012, $46 \%$ of all credits were awarded to coolant factories, mostly in developing countries. ${ }^{31}$ These companies realized that they could generate 11,700 times as many credits by destroying a tonne of HFC-23 than by capturing a tonne of $\mathrm{CO}_{2}$. Companies responded by producing enormous volumes of HCFC-22 so that they could generate credits by destroying (very cheaply) the HFC-23 that is its waste byproduct. Some of the companies generating CDM credits from the capture of HFC-23 earned nearly twice as much (an average of US\$20-40 million each year) from the sale of credits as from the production of HCFC-22. ${ }^{32}$ Indeed, many of the plants operated only until they had produced (and destroyed) the maximum amount of HFC-23 eligible for credits and then shut down operations until the following year. ${ }^{33}$ Companies went out of their way to use inefficient manufacturing processes to maximize the production of coolant gases and waste HFC-23. ${ }^{34}$ In 2012, EU regulators caught on to the scheme and declared that it would no longer accept CDM credits for the destruction of HFC-23. ${ }^{35}$ The United Nations (UN) refused to award credits to any factories that were not already in the business of producing HCFC-22, or that

\footnotetext{
${ }^{27}$ M.-C. Frunza, D. Guegan and A. Lassoudiere, 'Missing Trader Fraud on the Emissions Market', 18:2 Journal of Financial Crime (2011), 183. See also Peter Martin \& Reece Walters, 'Fraud risk and the visibility of carbon.’ 2 International Journal for Crime, Justice and Social Democracy, (2013): 27.

${ }^{28}$ Gunnar Myhre et al, 'Anthropogenic and Natural Radiative Forcing' in Thomas F Stocker et al (eds), Climate Change 2013: The Physical Science Basis. Contribution of Working Group I to the Fifth Assessment Report of the Intergovernmental Panel on Climate Change (Cambridge University Press 2013) 659).

${ }^{29}$ See Climate Change Connection ' $\mathrm{CO}_{2}$ Equivalents' available at

https://climatechangeconnection.org/emissions/co2-equivalents/

${ }^{30}$ See also M. Wara, n. 18 above, at 1782.

${ }^{31}$ E. Rosenthal and A. Lehren, 'Carbon Credits Gone Awry Raise Output of Harmful Gas', New York Times (9 August 2012).

${ }^{32}$ Ibid.

${ }^{33}$ Ibid.

34 Ibid.

35 J. Siciliano, 'EPA Slated to Offer Regulatory Plan to Address Concerns Over RINs Fraud', InsideEPA Environmental Policy Alert (25 July 2012).
} 
expanded production of the coolant. ${ }^{36}$ In China, some companies who were no longer able to earn credits for destroying HFC-23 have resorted to venting it into the atmosphere. ${ }^{37}$

Clearly, the lack of verifiable performance standards in the CDM provided an incentive to unnecessarily increase the production of HCFC-22. The absence of a verification framework that calibrated the destruction of HFC-23 with particular projects created the space for fraud. As Michael Wara puts it, '[t]he economics of HFC-23 projects create incentives for strategic behavior that, if left unchecked, would undermine the environmental efficacy of the CDM' ${ }^{38}$ Had robust performance standards been incorporated into the scheme right from the start, it would not have taken the EU and the UN as long as it took to catch on this scheme that almost destroyed the CDM. The case also highlights the lack (and importance) of rule of law safeguards that are designed for particular trading regimes. Whilst the design of the CDM assumes a functional level of rule of law standards relating to trade in financial and similar instruments, the various cases of manipulation in relation to the CDM demonstrated that this assumption cannot be taken for granted.

The third example is the Polish biodiesel fraud highlighted at the beginning of this article. The case relates to the national renewable energy action plans set up under RED and FQD; and which create a sustainability regime for biofuels including the criteria for fuel traders and a framework for monitoring by the EU Commission. Under the FQD, the national renewable energy action plans must ensure that fuel suppliers reduce fuel greenhouse gas emission intensity by $10 \%$ by 2020 through improvements in efficiency in the fossil fuel chain, increased use of biofuels, and, among other measures, the development of alternative and less carbon-intensive power trains. It is under this mandate that Poland has passed a number of regulations under the Fuel Quality Monitoring and Control Act (FQM). ${ }^{39}$ These regulations set the standards for the blending of hydrocarbon fuels, including diesel, with biomass-based liquid biofuels. In contravention of the standards required by the FQM and the Market Abuse Regulation, ${ }^{40}$ a number of Polish biodiesel traders were simply adding extra diesel to the volumes intended for blending and then subsequently shipping these volumes into the domestic and other EU markets as biodiesel.

This case demonstrates the risks posed by the absence of stringent regulatory oversight, a lack of transparency standards and the absence of verifiable performance standards. Indeed, the EBB speculates that this clearly fraudulent behaviour is due to weak licensing and oversight by the Polish authorities. ${ }^{41}$ The omission to require these standards under the RED and FQD has put at risk the integrity of the whole environmental services market in biodiesel.

It is impossible to know how many other cases of defrauding and manipulation of environmental credit trading markets have yet to be discovered. However, these three cautionary tales illustrate the need for building operational safeguards into programmes that create environmental markets. Meaningful safeguards will protect against abuses that

\footnotetext{
${ }^{36}$ See E. Rosenthal and A. Lehren, n. 31 above; M. Wara, n. 17 above, at 1785.

${ }^{37}$ See J. Siciliano, n. 35 above; see also M. Wara, n. 17 above, at 1789.

${ }^{38}$ See M. Wara, n. 17 above, at 1783.

${ }^{39}$ Act of 25 August 2006 (Journal of Laws of 2014(1728)) and of 2015(1361).

${ }^{40}$ Regulation 596/2014/EU of 16 April 2014 on Market Abuse (Market Abuse Regulation) and Repealing Directive 2003/6/EC of the European Parliament and of the Council and Commission Directives 2003/124/EC, 2003/125/EC and 2004/72/EC, [2014] OJ L173/1.

${ }^{41}$ See EBB, n. 1 above.
} 
undercut environmental protection goals and allow participants to reap undeserved profits within the operation of markets for ecosystem services.

The preceding cases demonstrate the importance of stringent operational standards, including informational safeguards, transparency standards, rule of law safeguards, verifiable performance standards, and financial fidelity rules, in ensuring the efficacy of environmental markets. In the next section, the article unpacks this set of operational safeguards and argues that each one is indispensable to a well-functioning and accountable market in ecosystem services.

\section{PREREQUISITES FOR A WELL-FUNCTIONING ENVIRONMENTAL MARKET}

Any viable environmental markets must have a number of baseline institutional prerequisites. $^{42}$ These include a clear allocation of authority to administer the trading programme to public entities, ${ }^{43}$ coupled with the provision of adequate funding to such public agencies, ${ }^{44}$ a clear framework for the assignment of property rights to foster confidence in the security of credit transactions and to avoid conflicting claims to rights attendant to trading credits, ${ }^{45}$ and a stable political environment. ${ }^{46}$

However, the cases analysed above demonstrate that these prerequisites alone are not enough for well-functioning environmental markets. In addition to these institutional prerequisites, it is critical to ensure that they are supported by a set of operational safeguards that ensure market integrity. The following sections describe the role of each of these operational safeguards in creating an accountable market in ecosystem services that minimizes opportunities for fraud and abuse.

\section{INFORMATIONAL SAFEGUARDS}

Closely related to information and transparency standards is the requirement for competent regulatory oversight. Regulatory supervision for markets for ecosystems will likely be ineffective if neither the government nor the public are without access to key information.

\footnotetext{
${ }^{42}$ See C. Giupponi et al., 'A Pilot Study on Payment for Ecological and Environmental Services in Lashai Nature Reserve, China', in: P. Kumar and R. Muradian, Payments for Ecosystem Services (Oxford University Press, 2009), 110, at 114. See also Simanti Banerjee et al. 'How to Sell Ecosystem Services: A Guide For Designing New Markets', 11 Frontiers in Ecology and the Environment (2013), 297, at 297-8.

${ }^{43}$ AJ van Teeffelen, et al, 'Ecological and Economic Conditions and Associated Institutional Challenges for Conservation Banking in Dynamic Landscapes' 130 Landscape and Urban Planning, (2014) 64, at 68 ('Effective conservation banking requires active regulation to design and enforce trading rules, and this is typically the role of government administrations...As with every regulation-driven policy instrument, a functioning public administration is therefore a necessary precondition, even if the said instrument is labelled as "market-based". For designing and implementing conservation banking a public administration must fulfil a number of tasks.. See also ibid., at 114-115.

${ }^{44}$ For an analysis of the impact of inadequate financial support for agencies charged with administering environmental, health and safety regulatory programmes, see R. Steinzor and S. Shapiro, The People's Agents and the Battle to Protect the American Public (University of Chicago Press, 2010), at 54-71 (describing the consequences of 'hollow government').

${ }^{45}$ See M. Smith et al. (Eds.), Establishing Payments for Watershed Services (IUCN, 2006), at 75; G. Achterman and R. Mauger, n. 22 above, at 317-318. According to one account, the operation of the CDM has been hampered by unclear property rights, among other factors. K. Chopra et al. (eds.), Millennium Ecosystem Assessment, Ecosystems and Human Well-being: Policy Responses (2005), available at: http://www.millenniumassessment.org/documents/document.772.aspx.pdf, vol. 3 (Contents, foreword, preface), at 7.

${ }^{46}$ See C. Giupponi et al., n. 42 above, at 114-115.
} 
Consequently, regulators must put in place measures, including mandatory reporting, inspections and monitoring. The function of these tools is, first, to verify that the ecosystem services supposedly being provided by market participants are actually being supplied and, second, to verify that the result is effective protection in a manner consistent with statutory or regulatory goals. ${ }^{47}$ In this regard, the authors of the Millennium Ecosystem Assessment argued that '[e]ffective monitoring, assessment, and reporting is a key to success in allocating ecosystem services and implementing response options'. ${ }^{8}$ The information provided by monitoring, inspection and reporting can provide feedback on the ongoing success or failure of transactions in environmental markets. It allows for mid-course corrections and the initiation of enforcement action if regulatory violations or breaches of conditions on project approval have occurred. ${ }^{49}$

It is essential that monitoring occurs on at least two levels. First, it needs to ensure that the services actually being provided by the sellers match the services that credit buyers were excused from delivering. Second, monitoring is needed to check whether individual trades and market-based programmes in the aggregate are actually achieving regulatory goals. ${ }^{50}$ With respect to the first level, it is important to evaluate whether credit sellers are fulfilling the commitments that allowed buyers to escape regulatory requirements. ${ }^{51}$ At the second level, if ambient monitoring shows that the intended environmental protection benefits of trading are not actually being achieved, programme adjustments should ensue. ${ }^{52}$

Reporting requirements for market participants are essential because, as the instances of fraud and abuse discussed above indicate profit-motivated buyers and sellers of environmental credits have incentives to cheat. Such incentives must necessarily be nullified by regulatory oversight. $^{53}$

Within the EU, the Aarhus Convention's provisions on access to environmental information were implemented through Regulation 1367/2006. ${ }^{54}$ This Regulation sets out the basic terms and conditions for granting access to environmental information held by or for public authorities. It aims to achieve the widest possible systematic availability and dissemination of information to the public. Despite this framework, access to information has not been uniformly applied across all EU ecosystems market mechanisms. For example, there have

\footnotetext{
${ }^{47}$ L. McAllister, 'The Enforcement Challenge of Cap-and-Trade Regulation', 40:4 Environmental Law (2010), 1195 , at 1198 .

${ }^{48}$ See K. Chopra, n. 44 above, vol. 3, at 4.

${ }^{49}$ See G. Achterman and R. Mauger, n. 22 above, at 329 (' $[\mathrm{t}]$ he public and environmental NGOs should expect trades to include meaningful ecosystem functions, to be subject to objective and meaningful monitoring and transparent data collection about trades, and to reassess their goals continually to assure they are being met'); M. Stanton, 'Payments for Freshwater Ecosystem Services: A Framework for Analysis', 18:1 Hastings WestNorthwest Journal of Environmental Law and Policy (2012), 189, at 270 ('[m]onitoring also enables decision makers to adjust and improve the design of the program over time and enforce penalties whenever there is a breach of contract').

${ }^{50}$ See G. Achterman and R. Mauger, n. 22 above, at 331; D. Driesen and S. Ghosh, n. 23 above, at 94-96.

51 See J. Wilkinson and R. Bendick, 'The Next Generation of Mitigation: Advancing Conservation Through Landscape-Level Mitigation Planning', 40:1 Environmental Law Reporter (2010), 10023, at 10035.

${ }^{52}$ Cf. L. McAllister, n. 47 above, at 1200 ('[a]ccurate monitoring is also critical to whether the program's environmental goal the overall cap imposed on all the regulated sources is truly attained').

${ }^{53}$ L. Wayburn and A. Chiono, 'The Role of Federal Policy in Establishing Ecosystem Service Markets', 20:2 Duke Environmental Law and Policy Forum (2010), 385, at 410.

${ }^{54}$ Regulation 1367/2006/EC on the Application of the Provisions of the Aarhus Convention on Access to Information, Public Participation in Decision-making and Access to Justice in Environmental Matters to Community institutions and bodies, [2006] OJ L264/13. See also Directive 2003/4/EC on Public Access to Environmental Information and Repealing Directive 90/313/EEC, [2003] OJ L41/26.
} 
been concerns regarding the lack of ETS data availability and transparency, which have allowed the multiple resale of permits and VAT fraud to take place. In its defence, the Commission has argued that it has taken measures to improve data availability and transparency. ${ }^{55}$ It points out that exchanges and other organized trading venues display anonymized information about bids, offers, trades and closing prices for market participants, and that this information is also available to the general public after a small delay. ${ }^{56}$ However, this notwithstanding, information relating to over the counter transactions are still, in principle, not accessible to other market participants. This has allowed an opening for market abuse.

The European Commission argues that the ETS Directive gives it a specific monitoring role which is linked, but not limited to, the introduction of auctioning as the main allocation method. ${ }^{57}$ The Commission adds that as financial intermediaries and power companies are the main participants on the European carbon market, any examination of the level of market oversight has to take account of more general legislation relating to both financial and energy markets. The former includes the Market Abuse Directive ${ }^{58}$ (which applies to those emission allowance derivatives which are regarded as financial instruments and traded on regulated markets) and the Markets in Financial Instruments Directive. ${ }^{59}$ Adopted in November 2010, the Auctioning Regulation does two things. It establishes a regulatory framework for the auctioning of emission allowances in the 2013-2020 trading period, ${ }^{60}$ and it increases regulatory oversight by, inter alia, broadening the scope of the Market Abuse and Markets in Financial Instruments Directives in the carbon market by extending to auctioning participants a number of measures stemming from the Anti-Money Laundering Directive. ${ }^{61}$ However, the European Commission's role is flawed, relying as it does on the Commission policing itself. A more elegant solution would be for the Commission to usher in a regulatory oversight framework that makes use of third-party verification. This would likely enhance the effectiveness of regulatory oversight safeguards, because the self-interest of market participants may make self-monitoring suspect. Thus, verification, either by the government or by independent third parties, can perform a valuable function in checking abuse. ${ }^{62}$

\section{TRANSPARENCY STANDARDS}

Another key limitation is a lack of information and the absence of stringent transparency standards. According to the Millennium Ecosystem Assessment, '[i]nsufficient participation and transparency in planning and decision-making have been major barriers' to ecosystem protection, through market-based mechanisms and otherwise. ${ }^{63}$ Transparent decision making and meaningful opportunities for public participation are critical because the interests of

\footnotetext{
${ }^{55}$ Communication from the European Commission, Towards an Enhanced Market Oversight Framework for the EU Emissions Trading Scheme, COM(2010) 796.

56 Ibid.

${ }^{57}$ Ibid.

${ }^{58}$ Directive 2003/6/EC on Insider Dealing and Market Manipulation (Market Abuse), [2003] OJ L96/16.

${ }^{59}$ Directive 2004/39/EC on Markets in Financial Instruments Amending Directives 85/611/EEC and 93/6/EEC and Directive 2000/12/EC and Repealing Directive 93/22/EEC, [2004] OJ L145/1.

${ }^{60}$ Regulation 1031/2010/EU on the Timing, Administration and Other Aspects of Auctioning of Greenhouse Gas Emission Allowances Pursuant to Directive 2003/87/EC Establishing a Scheme for Greenhouse Gas Emission Allowances Trading Within the Community, [2010] OJ L302/1.

${ }^{61}$ Directive 2005/60/EC on the Prevention of the Use of the Financial System for the Purpose of Money Laundering and Terrorist Financing, [2005] OJ L309/15.

${ }^{62}$ See L. McAllister, n. 47 above, at 1210-1211 ('[w]ithout verification, self-reporters will become lax, and likely lean towards underreporting if that is in their self-interest').

${ }^{63}$ See K. Chopra et al, n. 42 above, vol. 3, at 3.
} 
traders may not correspond to the broader public interest. ${ }^{64}$ Transparency and public participation promote legitimacy by fostering trust in the system. ${ }^{65}$ Opportunities for public participation enable opportunities for those managing the trading programme to garner information from a diverse array of sources that may assist in identifying which trades (or aspects of trades) would best serve regulatory aims.

Within the EU, the principal framework for information and transparency in environmental decision-making is founded upon the Aarhus Convention. ${ }^{66}$ As the Convention's title suggests, one of its key pillars is public participation in environmental decision making, an obligation that is binding to both signatory States as well as EU institutions. ${ }^{67}$ Under this framework, it is clear that the development of environmental markets must be accompanied by robust information and transparency systems, or otherwise fail regulatory scrutiny.

The implication of these observations for environmental markets is twofold. Whilst the Aarhus Convention structure provides a theoretically robust framework for establishing accountability, the complicated nature of ecosystem services, and the instruments chosen to realize their value, may work to thwart the realization of Aarhus' transparency standards and ultimately the possibilities for ensuring accountability. Therefore, it is imperative that clear information and transparency standards are articulated in order to mitigate the risks arising from opaque or non-participatory frameworks. In this regard, the Aarhus Convention provides a very good starting point for articulating a regulatory framework that entrenches accountability as a key requirement for all environmental governance efforts - including the regulation of environmental markets.

Transparency and opportunities for potential market participants and nongovernmental organizations (NGOs) to participate are critical at all stages of the process. This includes rule development and review of specific trades. Public input at the retail level is particularly important because those potentially affected by projects that a trade would enable, are valued for the location-specific information they provide that would be difficult for government overseers to acquire. ${ }^{68}$ Equally, transparency in the transfer of funds is important. Salzman and Ruhl contend that markets can only work if knowledge of their existence is widespread, information about individual transactions is available, and mechanisms exist to allow

\footnotetext{
${ }^{64}$ See J. Salzman and J.B. Ruhl, 'Currencies and the Commodification of Environmental Law', 53:1 Stanford Law Review (2000), 607-94, at 668 ('[u]nlike children trading baseball cards, when trading involves the environment there are interests beyond those of the traders that must be taken into account').

${ }^{65}$ J. Salzman, A Policy Maker's Guide to Designing Payments for Ecosystem Services (2009), at p. 51, available at: http://scholarship.law.duke.edu/faculty_scholarship/2081/ ('Public participation ensures not only that the relevant stakeholders are involved but feel they have meaningfully participated in decisions - that their concerns have been heard. Broad participation provides decision-makers important information about the needs and concerns of relevant stakeholders and may also inject new, creative ideas into the program design. Moreover, stakeholders are more likely to support decisions in which they feel vested.')

${ }^{66}$ Convention on Access to Information, Public Participation in Decision-making and Access to Justice in Environmental Matters (Aarhus, 25 June 1998; in force 30 October 2001). The Convention has been applied through a raft of EU instruments; see Regulation 1367/2006/EC on the Application of the Provisions of the Aarhus Convention on Access to Information, Public Participation in Decision-Making and Access to Justice in Environmental Matters to Community Institutions and Bodies, [2006] OJ L264/13; Directive 2003/35/EC Providing for Public Participation in Respect of the Drawing Up of Certain Plans and Programmes Relating to the Environment and Amending with Regard to Public Participation and Access to Justice Council Directives 85/337/EEC and 96/61/EC, [2003] OJ L156/17; Directive 85/337/EEC on the Assessment of the Effects of Certain Public and Private Projects on the Environment, [1985] OJ L175/40.

${ }^{67}$ Directive 2003/35/EC, n. 66 above.

${ }^{68}$ See J. Salzman and J.B. Ruhl, n. 66 above, at 681 (arguing that the public should be allowed to comment on proposed individual mitigation sites).
} 
prospective traders to find trading partners and determine the prices at which transactions are taking place. ${ }^{69}$

One option for enhancing transparency at the project-level stage is the creation of a registry that permits interested members of the public to track transactions. ${ }^{70}$ For example, the Ecosystem Marketplace has become a 'one-stop shop' for information about markets and payment schemes for ecosystem services. ${ }^{71}$ The website is maintained by the Katoomba Group, and is designed to provide a comprehensive source of information on environmental markets around the world. ${ }^{72}$

\section{RULE OF LAW SAFEGUARDS}

Accountability is key to any market-based regulatory framework. All participants in the trading regime need to be held accountable for non-compliance with the law. This includes the government officials who administer the programmes as well as private individuals who invest and seek to gain in the operation of such markets. Rule of law safeguards should therefore be built into the operation of ecosystem service markets to establish consequences for non-compliance and procedures to impose those sanctions.

Access to the courts should be available to stakeholders, including interested NGOs, to challenge the ground rules for the operation of an ecosystem service market. In addition, judicial review should be available for agency approval of individual transactions. ${ }^{73}$ The statutes and regulations establishing programmes for markets in ecosystem services should specify penalties for violating regulatory requirements and contract terms, and authorize the government to impose or seek judicial imposition of those penalties.

Available penalties might include bond forfeiture, the withholding of future payments by credit buyers, financial penalties, permit suspensions or revocations, injunctions shutting down projects or requiring restoration, and even the imposition of criminal sanctions for behaviour such as wilful submission of false reports. ${ }^{74}$ Policy makers should consider making the entity that purchases credits legally responsible for its seller's failure to meet performance standards or inability to comply with programme requirements. By moving responsibility to a third entity, it is possible to ensure that someone other than the government becomes highly invested in successful ecosystem protection actions.

The threat of sanction imposition must be meaningful. This requires the adequate financing of enforcement agencies, and the independence of government officials from those who would profit from avoidance of the rules. A well-functioning market-based programme would include an additional safety net by authorizing judicial review of ongoing project

\footnotetext{
${ }^{69}$ J.B. Ruhl and J. Salzman, 'The Law and Policy Beginnings of Ecosystem Services', 22:2 Journal of Land Use \& Environmental Law (2007), 157, at 162.

${ }^{70}$ See M. Peters-Stanley, Back to the Future: State of Voluntary Carbon Markets (Ecosystem Marketplace, 2011), at 38 ('[t]o inspire consumer confidence in the quality of carbon offsets as financial instruments, a growing number of suppliers and standards are turning to registries for clarity of ownership and transparency').

${ }_{11}$ J. Salzman, 'A Field of Green? The Past and Future of Ecosystem Services', 21:2 Journal of Land Use \& Environmental Law (2006), 133, at 148.

${ }^{72}$ See <http://www.ecosystemmarketplace.com>.

${ }^{73}$ See G. Achterman and R. Mauger, n. 22 above, ('governments should create procedures that allow NGOs and the public to challenge transactions that are fraudulent or detrimental to public interest and to hold legally responsible parties accountable').

${ }^{74}$ See M. Smith et al., n. 43 above, at 82; J. Salzman, n.67 above, at 53.
} 
implementation, including performance of contract or regulatory requirements at the behest of private citizens and public interest groups. ${ }^{75}$

\section{VERIFIABLE PERFORMANCE STANDARDS}

Viable environmental markets must adopt performance standards for activities conducted by a credit seller to meet the regulatory obligations of a credit buyer. In this regard, it is critical that performance standards underlying market-based programmes are sufficiently clear and not so abstract that they become unverifiable. One way of ensuring that performance standards do not stifle trade is to utilize Salzman and Ruhl's distinction between wholesale and retail review of environmental trading. ${ }^{76}$ Wholesale review involves the creation of general rules governing trades, while retail review applies to individual transactions to ensure compliance with those rules and to verify that the promised environmental services are actually being provided. $^{77}$ With respect to wholesale review, those structuring an environmental trading programme must balance the ability of detailed trading rules to check abuses with the tendency of detailed rules to reduce the flexibility of market participants to craft, and oversight agencies to approve, innovative arrangements capable of achieving desired levels of protection efficiently. At the retail stage, the more extensive the review, the greater the probability that regulators will be able to halt fraudulent trades before they occur. There is a balance to be achieved, however. Extensive retail review increases transaction costs, which may preclude potentially beneficial trades because they are too costly to arrange and implement. ${ }^{78}$

\section{FINANCIAL FIDELITY RULES}

No market for environmental service scan eliminate the risk of fraud and abuse, nor can it exclude well-intentioned participation that falls short of achieving statutory environmental protection goals. Therefore, it is crucial that viable environmental markets require those participating in the market to provide financial assurances to guard against the possibility of project failure. ${ }^{79}$ An additional level of protection may be provided if those responsible for administering an ecosystem services trading programme require that funds to be used for mitigation be placed in segregated accounts to minimize the risk of diversion of those funds for non-authorized uses. Another option is to run alongside these markets robust insurance programmes that would compensate for losses in the event of project failure. These measures should be applied to bankers and others who have assumed the regulatory obligations of credit purchasers.

\section{FURTHER JUSTIFICATION FOR INTEGRATED OPERATIONAL SAFEGUARDS}

\footnotetext{
${ }^{75}$ See M. Smith et al., n. 43 above, at 75 ('Provision for citizen participation is important, including the right of citizens and non-governmental organizations to bring lawsuits for the purpose of enforcing the rules and contracts associated with payment schemes.'); J. Salzman and J.B. Ruhl, n. 66 above, at 683 (endorsing liberal citizen suit rights to enforce trading performance standards under strict standards of judicial review).

${ }^{76}$ See J. Salzman and J.B. Ruhl, n. 6 above, at 671-673 ('Put differently, if wholesale review resembles the government's oversight of a commodity market, then retail review requiring substantive approval by the government looks more like a barter market. ... The challenge lies in devising a program that enables the arbiter to "see" bad trades and provides the institutional authority and incentives to do something about them.')

${ }^{77}$ Ibid.

${ }^{78}$ Ibid., at 673.

${ }^{79}$ See, e.g., A. Davis, n. 20 above, at 350 (describing financial assurances in a wetlands banking scheme 'similar to a bond tied to project success').
} 
The operational safeguards suggested here are not only justified by an analysis of the cases discussed above. There is also a strong legal basis for insisting that these standards form part of the baseline legal arrangements for all EU environmental markets. In this regard, it is worth noting that key principles of international environmental law require that these standards are incorporated into any framework that seeks to deliver environmental protection. For example, a number of the Rio Declaration's principles ${ }^{80}$ would require that markets for ecosystems service apply the measures above. Similarly, some of the clearest obligations emerge from the Aarhus Convention. The treaty raises the obligations to provide transparency and opportunities for public participation in regulatory decision making and oversight for all environmental measures. These measures are binding on States and must be applied to market-based programmes in a systematic way.

Another very good reason for insisting on these operational safeguards is experience. The performance of market-based programmes that appear to have worked well have invariably included a number of the safeguards prescribed above. These programmes have experienced less episodes of fraud and manipulation than those that have not had any of these safeguards directly built into their legal and operational framework. ${ }^{81}$ Examples of such programmes include the EU's CAP land use programme and the US acid rain programme under Title IV of the federal Clean Air Act (CAA). ${ }^{82}$

Consequently, dealing effectively with cases of fraud and manipulation requires some effort at integrating the safeguards outlined above into the operations of market-based programmes. Such an approach is necessary because cases of fraud and manipulation do not neatly manifest themselves as failure of one particular safeguard. Often, it is a combination of failures that ultimately enables abuse. Therefore, integrating the standards outlined above would likely lower the operational risk profile of market-based programmes. It is also critical to ensure that the safeguards outlined above are applied together. This reduces the risk that one element of operations will incubate some operational vulnerability. Furthermore, deliberately designing these safeguards for particular environmental markets seems a more effective strategy rather than relying on general provisions. This is because custom-designed safeguards will likely address the specific risks attendant to a trading regime which vary from one market-based programme to the next. Finally, a cascade of robust operational safeguards is a likely catalyst for all-round good regulatory and operational practice throughout the functions of any market-based programme. Applying this set of safeguards constantly and consistently ensures that risks are minimized at each stage of trading.

\section{CONCLUSION}

EU frameworks for environmental markets are inadequate because they do not routinely prescribe a robust and integrated framework for operational safeguards beyond general

\footnotetext{
${ }^{80}$ See, for example Rio Declaration on Environment and Development, in: Report of the UN Conference on Environment and Development (UN Doc. A/CONF.151/26/Rev.1 (Vol. I), 14 June 1992), Annex, Principle 16 (on internalization of environmental costs, use of economic instruments, so that polluter should, in principle, bear the cost of pollution); Principle 15 (addressing the precautionary approach, and providing that lack of full scientific certainty not used as a reason for postponing measures to prevent degradation); Principle 10 (on participation, awareness and access to information, access to judicial and administrative proceedings, including redress and remedy); Principle 11 (on the need for effective environmental legislation, environmental standards and management standards); and Principle 19 (dealing with prior and timely notification and relevant information, consultation with others at early stage and in good faith).

${ }^{81}$ See R. Glicksman and T. Kaime, n. 6 above

8242 USC $\$ 7401$. See also 40 CFR $\S \S$ C, Parts 50-97 (Implementing regulations).
} 
institutional baselines. In some cases, this has allowed fraud and manipulation to take root and threaten the integrity of the concerned market-based programmes. However, this lack of provision presents a greater danger: environmental markets are yet to gain wide acceptance as viable regulatory options. Mounting cases of fraud and manipulation may force off the table an environmental protection tool which could yet prove very valuable as a method for internalizing costs.

To minimize the risk of fraud and manipulation, this article proposes a suite of operational safeguards that are drawn from not only the case studies analysed here but also have a strong legal and experiential basis. These safeguards address vulnerabilities that have allowed fraud and manipulation to take place in the past. It is critical to ensure that these safeguards are specially integrated into each market for environmental services, taking into account its particular risk profile. Integrated operational safeguards offer a better buffer against those that may seek to take advantage of the operations of the market-based programme as opposed to general provisions in the legal framework. More importantly, integrated safeguards ensure confidence in environmental markets as a viable tool for managing environmental policy.

The prescription of safeguard mechanisms is not a call for over-regulation but rather for an adaptive framework that addresses the risks before they emerge and is reactive enough to identify problems before they fester. The current European Commission's approach to dealing with cases of fraud and manipulation shows that it is reactive and fails to proactively apply lessons learned to new and existing environmental markets. This is not a sufficient methodology for a mechanism that will likely play a key role in environmental protection in the EU. It is therefore critical to apply an integrated set of standards to all environmental markets to ensure that risks from fraud and manipulation are minimized.

Thoko Kaime is a Senior Lecturer in Law and Socio-legal Studies Essex Law School. His work is an ongoing socio-legal critique of international legal arrangements which he expresses through a consideration of a number of critical issues in children's rights and sustainability governance. He has written extensively on these subjects, focusing on the intersection between law, legitimacy and public participation in international rule-making and policy implementation. Beyond Essex, Thoko is Senior Teaching Fellow at SOAS University of London; Convenor for Energy and Natural Resources at the International Environmental Law Research Centre; and co-Chair of the Community of Practice on Legal Aspects of Sustainable Access to Energy.

This contribution is based on a presentation made at the Sao Paulo University, Instituto de Energia e Ambiente-USP conference of 8 September 2015 on 'Realising Environmental Values'. The author thanks Ciara Remerscheid for her valuable research assistance. This contribution extends the normative discussion in: T. Kaime and R. Glicksman, 'A Comparative Analysis of Accountability Mechanisms for Ecosystem Services Markets in the United States and the European Union', 2:2 Transnational Environmental Law (2013), 259. Itand focuses on specifically EU environmental markets; incorporates new cases studies and refines the methodology and justification for the prescribed safeguards. 